\title{
Volcanic hazard and risk assessment in a multi-source volcanic area: the example of Napoli city (Southern Italy)
}

\author{
I. Alberico ${ }^{1}$, P. Petrosino ${ }^{2}$, and L. Lirer ${ }^{2}$ \\ ${ }^{1}$ Centro Interdipartimentale Ricerca Ambiente (CIRAM), Università degli Studi di Napoli Federico II, \\ Via Mezzocannone 16, Napoli, Italy \\ ${ }^{2}$ Dipartimento di Scienze della Terra Università degli Studi di Napoli "Federico II", Largo S. Marcellino 10, Napoli, Italy
}

Received: 20 November 2009 - Revised: 22 December 2010 - Accepted: 22 December 2010 - Published: 7 April 2011

\begin{abstract}
The possible emplacement of pyroclastic fall and flow products from Campi Flegrei and Somma-Vesuvio represents a threat for the population living in Napoli city. For this area, the volcanic hazard was always partially investigated to define the hazard related to the Campi Flegrei or to the Somma-Vesuvio activity one at a time. A new volcanic hazard and risk assessment, at the municipality scale, as a vital tool for decision-making about territorial management and future planning, is presented here.

In order to assess the hazard related to the explosive activity of both sources, we integrated the results of field studies and numerical simulations, to evaluate the future possibility for Napoli to be hit by the products of an explosive eruption. This is defined for the Somma Vesuvio central volcano through the sum of "field frequency" based on the thickness and distribution of past deposits (Lirer et al., 2001), and for the Campi Flegrei volcanic field by suitably processing simulated events based on numerical modelling (Alberico et al., 2002; Costa et al., 2009). Aiming at volcanic risk assessment, the hazard areas were joined with the exposure map, considered for our purposes as the economical value of artefacts exposed to hazard. We defined four risk classes, and argued that the medium and low-very low risk classes have the largest extent in Napoli municipality, whereas only few zones located in the eastern part of the city and in the westernmost coastal area show a high risk, owing to the correspondence of high economical value and high hazard.
\end{abstract}

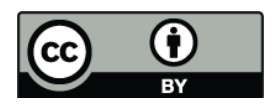

Correspondence to: I. Alberico (ialberic@unina.it)

\section{Introduction}

All the possible hazards posed by both anthropic and natural factors in metropolitan areas generally bring with them a very high risk, mainly due to the high exposure. Notwithstanding anthropic risks, which are beyond the object of this paper, Napoli mega-city is exposed to many natural risks.

First of all, earthquakes by both the Apennine chain tectonic seismic source and the Campi Flegrei and Somma Vesuvio volcanic sources can be felt in Napoli. Moreover, landslide phenomena can involve both the welded volcanic rock steep slopes of the hills bordering the city and the pyroclastic covers emplaced by past volcanic activity. The Neapolitan Yellow Tuff, a soft welded pyroclastic rock which makes up most of the Napoli underground, in the past was intensively exploited by man and now is crossed by a net of subterraneous galleries whose roofs often collapse. Flood events are very frequent as well, due to the geomorphological onset of the city, which mainly lies on narrow costal plains bordered by pyroclastic hills, whose slopes quicken the flow of sediment-laden waters toward the sea.

This paper deals with volcanic hazard, the most important cause of natural risk which Napoli is exposed to. As well as Auckland in New Zealand, in fact, Napoli is a mega-city overlying an active volcanic field but it is the only example in the world of a such inhabited city located in a multiple source volcanic area (Fig. 1).

Recently Lirer et al. (2010) drew a multi source hazard map encompassing the three active volcanic sources of Campania region (Campi Flegrei and Ischia island volcanic fields and Somma-Vesuvio central volcano), by taking into account all the explosive typologies occurred in the last $10 \mathrm{ka}$. Basing on this hazard map, the same authors zoned in detail the exposure in the endangered towns and drew a new risk map.

Published by Copernicus Publications on behalf of the European Geosciences Union. 


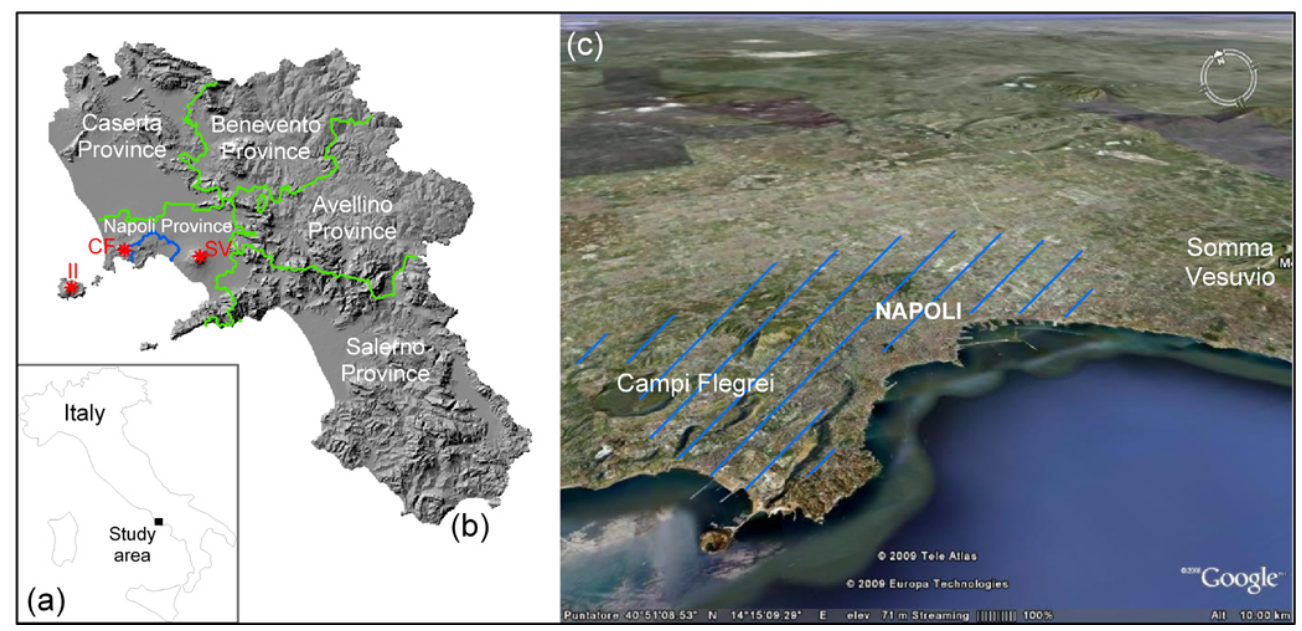

Fig. 1. Location map of Napoli city at national (a) and regional (b) scale, the green lines are the provincial boundaries, the blue line is the Napoli city boundary, the red stars are the locations of Ischia island (II), Campi Flegrei volcanic sources (CF) and Somma-Vesuvio volcanic sources (SV) active volcanoes. Location of the city with respect to the Somma-Vesuvio and Campi Flegrei active is also shown in the 3-D overview (c).

The careful observation of this map highlights the problem of Napoli mega-city, which stands in an area exposed to hazard both from Campi Flegrei and Somma Vesuvio. This consideration, joined to the high exposure both in terms of human lives and goods, was worth a more detailed assessment of volcanic hazard and risk for Napoli city.

Previous studies about volcanic hazard assessment mainly deal with single sources one at a time and, as a consequence, the weak position of Napoli city was often overlooked. The municipalities N. 9 (Pianura-Soccavo) and N. 10 (BagnoliFuorigrotta) of the city, however, fall within the Campi Flegrei caldera and were exposed, in the past, to the deposition of both pyroclastic current and pyroclastic fall products of Campi Flegrei. According to Orsi et al. (2004), who took into account the whole of the explosive activity occurred at Campi Flegrei after the NYT (15 ka), Napoli city has a low frequency of occurrence of eruptions emplacing a pyroclastic fall layer loading $3 \mathrm{kN} / \mathrm{m}^{2}$ (roof collapse threshold). Alberico et al. (2002) found low to intermediate values of probability of new vent opening in the Napoli area pertaining to Campi Flegrei, and deduce that pyroclastic currents of low to medium size eruptions mainly remain confined inside the Campi Flegrei caldera. de Vita et al. (1999) and Alberico et al. (2005), however, found that the Monte Spina eruption pyroclastic currents overtopped the Posillipo hill and were emplaced, although with reduced thickness, in the present ancient centre of Napoli. Orsi et al. (2004) identified Campi Flegrei pyroclastic flow deposits in the sector occupied by the western part of the city of Napoli and on the northern slopes of the Camaldoli hill.

As far as Somma Vesuvio activity is concerned, only a few papers deal with the possible hazard posed by this volcano to the Napoli city. As a matter of fact, pyroclastic fall products of high VEI eruptions of Somma Vesuvio are mainly spread towards the NE, and in the past $25 \mathrm{ka}$ no plinian column was diverted towards the NW from the volcano. By simulating explosive events and investigating the wind directions, Barberi et al. (1990), Cioni et al. (2003), Rolandi et al. (2007), Macedonio et al. (2008), Daniele et al. (2009) and Rolandi (2010) reach almost the same conclusion: prevailing winds at the higher altitudes blow from the $\mathrm{W}$, as a consequence a possible future plinian event most probably will spread its products in the eastern sectors from the volcano and they would therefore spare Napoli. Daniele et al. (2009), however, prove the high variability of wind fields in the lowermost layers of atmosphere, and from this consideration descend the conclusion that a possible future violent strombolian-subplinian event, displaying column heights lower than those of a plinian eruption, could endanger Napoli city.

As far as pyroclastic density currents from Somma Vesuvio are concerned, Alberico et al. (2005) found buried pyroclastic flow deposits ascribable to the Ottaviano eruption (8 ka-Rolandi et al., 1993a) in many boreholes in the eastern zone of Napoli, whose thickness decreases toward the southwest. Furthermore, Mastrolorenzo et al. (2006) identified a 3- to 0.5 -m-thick pyroclastic surge deposit that was emplaced by the passage of the last and most powerful Avellino surge cloud sequence, as already pointed out by Santacroce (1987) and Cioni et al. (1999).

The first attempt to give a synoptic view of the hazard and risk posed by Campi Flegrei and Somma Vesuvio was made by Petrosino et al. (2004), who drew a hazard map encompassing the last $10 \mathrm{ka}$ of activity at both sources. Moreover, they joined territorial planners in the investigation of the social and urban evolution in the last century of territory exposed to risk in Campania. 


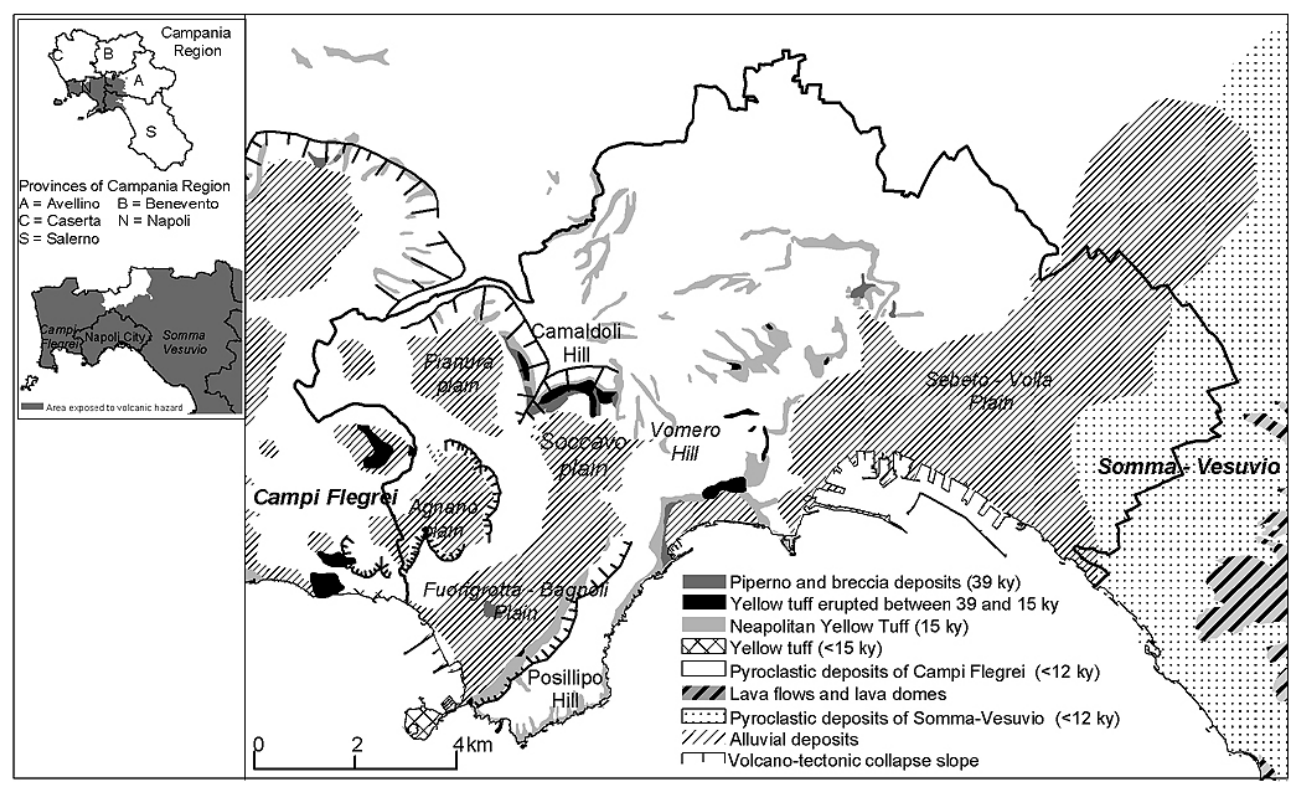

Fig. 2. Geological sketch map of Napoli city.

Main aim of the present paper, which follows the steps of Petrosino et al. (2004), is to use the multi-source hazard map of Lirer et al. (2010) as a starting point to shade a new light on volcanic risk assessment for Napoli city. We think that this is a necessary scope to be pursued, because of the present complex relationship among scientific community, territorial planners and local authorities existing in Napoli. Since a couple of years ago, in fact, both Napoli city municipal authorities are revising the territorial zoning for planning new urban settlement within the city and Civil Protection is updating the volcanic risk emergency plans.

The results of the research here presented could be helpful on the long term, for territorial planners who ought to take in the right account the impending volcanic risk. Moreover, on the short term, when a volcanic crisis is on going, they can represent the starting point for more detailed maps, useful to manage the evacuation of the endangered population.

\section{Geological outlines of the metropolitan area}

The Napoli city grew in the complex active multi-source volcanic area of the Campi Flegrei volcanic field and the Somma-Vesuvio district. It is situated in a large graben, broken into smaller horst and graben structures, connected to the Pliocene-Quaternary Tyrrhenian margin evolution (Carrara et al., 1973, 1974; Ippolito et al., 1973; D’ Argenio et al., 1973; Finetti and Morelli, 1974; AGIP, 1987). In particular the western sector of the city is set on the horst-type structure of Campi Flegrei caldera, the eastern one is located in a smaller graben, bounded to the east by another horst which hosts the Somma-Vesuvio volcano. The substratum of the city is made up of volcanic rocks, marine and alluvial deposits in response to regional, volcano tectonics and sea level changes occurred during the Holocene (Cinque et al., 1985) (Fig. 2).

Neapolitan Yellow Tuff (NYT, 15 ky, Deino et al., 2004) forms the framework of most of the hills in Napoli. According to the field surveys (Rittmann et al., 1950; Di Girolamo et al., 1984; Bellucci, 1994; Bellucci et al., 2006; Lirer, 2008) along a SW-NE trend, this formation overlays the Tufi Biancastri (Camaldoli Hill) or the Campanian Ignimbrite (39 ky, De Vivo et al., 2001 - Capodichino and Poggioreale).

At Posillipo, Vomero and San Martino hills the NYT overlays the Tufi Antichi (Rittmann et al., 1950; Scherillo, 1957). Recent studies carried out on San Martino hill highlighted the presence of products associated to the Campanian Ignimbrite between the NYT and the Tufi Antichi (Perrotta et al., 2006; Bellucci et al., 2006) These latter products were probably emplaced by the vents of an ancient volcanic field in the Napoli city area (Paleo Campi Flegrei - Lirer et al., 2001), as the volcano relicts evidenced by the paleomorphology before the deposition of NYT (Alberico et al., 2005) testify. The deposits contain many ballistic fragments up to few meters in diameter, indicating proximity to the source (Orsi et al., 1996).

The NYT is overlain by the fall products of the last $10 \mathrm{ka}$ explosive activity of Campi Flegrei, decreasing in thickness from $15 \mathrm{~m}$ to some tens of decimetres towards the eastern sector of the city. The same products are found in sparse boreholes of Agnano, Bagnoli-Fuorigrotta, Pianura and Soccavo, with a mean thickness of $30 \mathrm{~m}$ (Di Vito et al., 1999; Alberico et al., 2005). 
The Agnano plain, generated by a volcano-tectonic collapse following the Agnano-Monte Spina eruption (4.1 ka de Vita et al., 1999), has a poly-crateric morphology linked to four main eruptive events: Grotta del Cane, Monte S. Angelo, Monte Spina and Pigna S. Nicola (Di Girolamo et al., 1984). The analysis of few boreholes drilled in this plain showed a stratigraphic sequence formed from the bottom to the top by S. Teresa, La Pietra, Nisida, Monte S. Angelo, Grotta del Cane, Monte Spina and Astroni volcanic products. This sequence is the same surveyed in the outcrops around the Agnano crater rim (Di Girolamo et al., 1984; Di Vito et al., 1999). In the subsurface are also found marine and swampy deposits, related to the volcano-tectonic evolution occurred in the middle of the Holocene, when the northern half of the caldera was uplifted, while the southern half remained under the sea level to form the present bay of Pozzuoli (Cinque et al., 1997). The marine deposits outcropping at La Starza marine terrace were interpreted as the results of two processes acting at the same time: marine sedimentation and volcanic activity mainly characterized by pyroclastic flow deposition (Cinque et al., 1985).

The Bagnoli - Fuorigrotta volcano-tectonic plain is filled in with the products of the post-NYT explosive activity; in only one deep drill-hole this formation was found at $150 \mathrm{~m}$ depth. In the southern part of the Bagnoli-Furigrotta plain, as in the Agnano plain, the volcanic products are interbedded to marine deposits (Cinque et al., 1985; Di Vito et al., 1999; Alberico et al., 2005).

At Pianura and Soccavo inland plains the boreholes indicate the presence of pyroclastic deposits of the Agnano Monte Spina, Astroni and Monte S. Angelo eruptions. In detail, the Astroni deposits are mainly drilled at Pianura and in the north-western zones of Soccavo plain, while the southeastern zone of the Soccavo and Fuorigrotta plains are characterized by a wider emplacement of Monte Spina and Monte S. Angelo formations. Only few drill holes reach the underlaying formation of Tufi Gialli Stratificati (S. Teresa, La Pietra, Nisida) or the NYT (Fig. 3).

In the eastern part of the city, corresponding to the SebetoVolla Holocene coastal plain, were drilled the effusive and explosive products of Somma-Vesuvio and the explosive products of Campi Flegrei piled up during the last $15 \mathrm{ka}$. The stratigraphic successions of over one hundred drill holes were investigated (Bellucci, 1994; Alberico et al., 2005) and made it possible to deduce the presence of marine and alluvial deposits embedded to volcanic products. In the western sector of Sebeto-Volla plain prevails the NYT that thins toward the eastern sector, where lava flows and pyroclastic flow deposits of the Somma-Vesuvio eruptions are predominant (see Fig. 2).

\section{Multi-source hazard map for Napoli city}

The volcanic hazard for Napoli is worth a detailed investigation, since the city is comprised between the two active volcanic areas of Campi Flegrei and Somma-Vesuvio and, in as much, displays one of the highest population rates of the whole Europe (about one million people with a population rate reaching apex values of $5000 \mathrm{inh} / \mathrm{km}^{2}$ ).

In order to zone the territory of Napoli municipality with regard to hazard posed by the possible future explosive activity of Campi Flegrei and Somma-Vesuvio, the volcanic hazard map of Napoli municipality, given a volcanic event occur (randomly chosen by Campi Flegrei and Vesuvio) was worked out using the potentiality of spatial analysis of Geographic Information System (GIS) framework (Araña et al., 2000; Pareschi et al., 2000; Gómez-Fernández; 2000; Behncke et al., 2006; Felpeto et al., 2007; Toyos et al., 2007; Widiwijayanti et al., 2009).

Past explosive products of Campi Flegrei and SommaVesuvio hit the eastern and western sector of the city in a different way as a consequence of the size of explosive eruptions and the topographic onset. The distribution of these products has been retraced in detail thanks to field surveys, mainly up to the late Sixties, when several building excavations were performed in the city area (Lirer, 2008) and, more recently, thanks to the analysis of drilled stratigraphic sequences (Di Vito et al., 1999; Isaia et al., 2004; Alberico et al., 2005; Bellucci et al., 2006). The identification of the area invaded by the products of the two volcanic sources, for the long term, allows the forecasting of the possible hazard in case of a future explosive event.

\subsection{Western sector}

The products of the two main plinian-subplinian eruptions occurred at Campi Flegrei after the NYT eruption, Pomici Principali (ca. 10.3 ka - Alessio et al., 1973) and Monte Spina (ca. $4.1 \mathrm{ka}$ - de Vita et al., 1999), blanketed the main part of territory inside the Campi Flegrei caldera and extended toward the east, up to pre-Apennines (Costa et al., 2009; Lirer et al., 2010). Pyroclastic fall deposits of lower magnitude eruptions almost exclusively blanketed the areas close to the different vents (Di Girolamo et al., 1984; Di Vito et al., 1999; Costa et al., 2009). Only the fall deposits of Astroni eruption (3.8 ka - Di Vito et al., 1999) were found by Isaia et al. (2004) in the Napoli area.

The area reached by pyroclastic flow products, emplaced in the same time-span, corresponds to the Campi Flegrei caldera (Lirer et al., 2001); these products usually thicken in the morphological lowland and thin toward the slopes that border the Agnano, Fuorigrotta, Soccavo and Pianura plains (Rosi and Sbrana, 1987). Moreover, field data testify to the capability of only very dilute pyroclastic currents to surmount the Campi Flegrei caldera rim $(200 \mathrm{~m}$ average altitude). In particular, de Vita et al. (1999), highlighted 


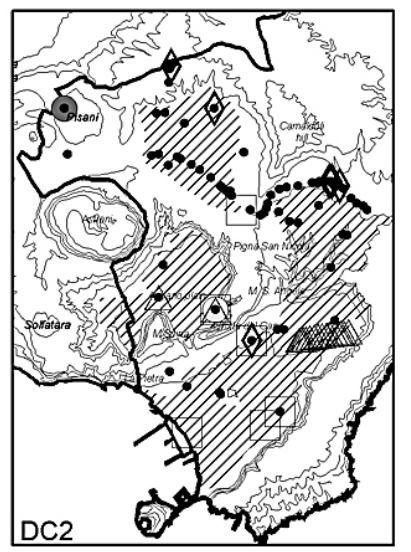

DC1 - Senga pyroclastic deposits (3.7 ky)

DC2 - Astroni pyroclastic deposits (3.8 ky) DC3 - Monte Spina pyroclastic deposits (4.1 ky) DC4 - Monte S. Angelo pyroclastic deposits (4.0 ky) DC5 - S. Teresa, La Pietra, Nisida pyroclastic deposits

$\diamond$ Neapolitan Yellow Tuff
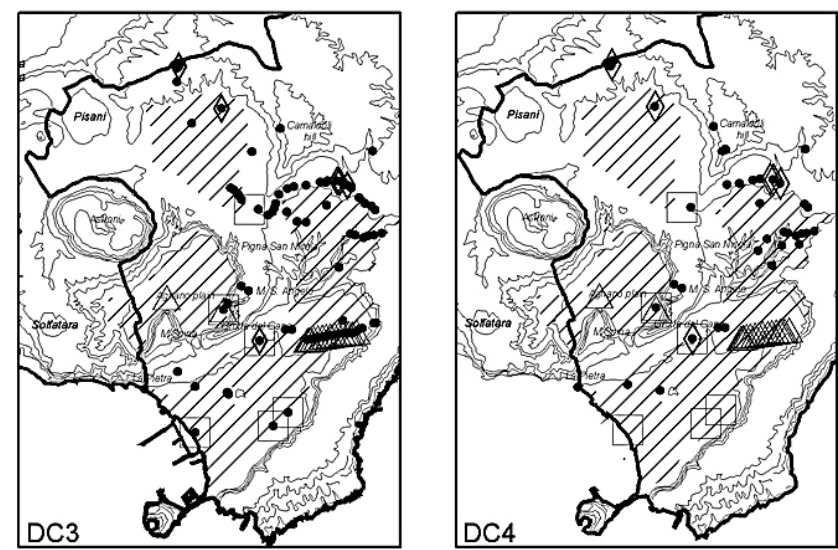

Alluvial deposits

Marine and beach deposits

Fig. 3. Spatial distribution of boreholes showing the presence of pyroclastic deposits in the western area of Napoli city.

that the pyroclastic flows of the main phase of the Agnano Monte Spina eruption, channelled along morphological saddles, reached towards the east the city of Napoli and overtopped the north-eastern slopes of the Pianura plain. On the north-western side of the Camaldoli hill these dilute pyroclastic flows channelled into the gullies and reached the Aversa plain, $15 \mathrm{~km}$ far from the vent. These data are corroborated by the results of Todesco et al. (2006), which applied a numerical model to define hazard flow variables along different topographic profiles in the south-eastern sector of Campi Flegrei. They infer that for large events (Agnano Monte Spina mass eruption rate $=1 \times 10^{8}$ ) obstacles like the Posillipo hill do not protect the city of Napoli but reduce flow velocity and dynamic overpressure; for small eruptions (mass eruption rate $=2.5 \times 10^{7}$ ) the flow is stopped by the Posillipo hill (200 $\mathrm{m}$ average altitude).

\subsection{Eastern sector}

As previously stated in the introductory section Napoli was somewhat spared by pyroclastic fall products of plinian events occurred at Somma Vesuvio in the last $25 \mathrm{ka}$. The influence of wind on the direction of main dispersal axis was investigated for plinian, sub-plinian and violent strombolian eruptions (Barberi et al., 1990; Cioni et al., 2003; Rolandi et al., 2007; Macedonio et al., 2008; Rolandi, 2010). Prevailing winds blow mainly from west throughout the entire year for altitudes of up to $20 \mathrm{~km}$. Over $18-20 \mathrm{~km}$ the summer winds show a prevailing east provenance (Costa et al., 2009), even though the low velocity which characterizes the wind at this altitude is not expected to significantly affect the main dispersal axis (Barberi et al., 1990), which shows a prevailing easterly direction.
Following the conclusion of Daniele et al. (2009), who hypothesise that low-intermediate size explosive eruptions could emplace pyroclastic fall products also in western direction, in the present research we carefully investigated the dispersal of past strombolian eruptions, which displayed an almost round-shaped isopach map. During the protohistoric period, between the Avellino (3.5 ka) and Pompei (79 AD) plinian eruptions, three main events were recognized by Rolandi et al. (1998). The last protohistoric eruption of Rolandi et al. (1998) was interpreted as four distinct violent strombolian to vulcanian eruptions by Andronico et al. (2002). The main dispersal axis of these eruptions changes from north-northeast to south-southeast. Between Pompei (79 AD) and 472 AD, only one event, the explosive eruption of $203 \mathrm{AD}$ was identified as strombolian activity with a dispersal axis toward southeast. During the Medioeval period (472-1631) four strombolian-freatoplinian eruptions took place, mainly dispersed toward the east. The post-1631 eruptions range between the "violent strombolian" and "subplinian", the column height of these eruptions never exceeds $10 \mathrm{~km}$ (Arrighi et al., 2001) and main dispersal axis varies from northeast to southeast.

On the whole, our analysis brings to the conclusion that even strombolian-subplinian events occurred in the past at Somma Vesuvio dispersed their products towards the east, and a north-western distribution, involving Napoli city, results quite improbable. The presence of the fall products of the third protohistoric eruption, however, was recorded in some gravity cores drilled in the Napoli and Pozzuoli Gulfs (Di Lillo, 2001; Insinga et al., 2008). Moreover, ash falling on Napoli is reported in several coeval chronicles of past 1631 Somma Vesuvio activity. Very recently, Rolandi (2010) quotes the example of the 1906 Vesuvio eruption that was 
Table 1. Synthesis of historical chronicles describing the effect in Napoli city of pyroclastic fall deposits coming from Somma-Vesuvio.

\begin{tabular}{lll}
\hline Eruption size & Year & Description of activity \\
\hline Strombolian & 1649 & $\begin{array}{l}\text { Deposition of volcanic ash that, transported by the wind, reached Napoli at the end of } \\
\text { 1649 and over the next few years }\end{array}$ \\
Strombolian & 1654 & Whitish ash fell on Napoli \\
Strombolian & 1660 & At the end of the paroxysmal phase of this eruption whitish ash similar to that of 1654 fell on Napoli \\
Violent vulcanian & 1698 & The ash thrown out during the violent vulcanian explosions fell on Napoli \\
Vulcanian & 1707 & Dense ash fall blanketed Napoli \\
Strombolian & 1737 & Ash fall was recorded on Napoli \\
Strombolian & 1767 & On October 20th ash fell on Napoli \\
Strombolian & 1790 & There was significant explosive activity that led to the accumulation of ash in Napoli \\
Strombolian & 1794 & 5 mm of ashes piled up in Napoli \\
Violent strombolian & 1822 & Ash fell in Napoli \\
Violent vulcanian & 1895 & Ash reached Napoli borne by the wind \\
Violent strombolian & 1906 & Fall of reddish ashes reached Napoli \\
\hline
\end{tabular}

characterized by variable wind patterns, initially from the west and then from the east, producing tephra lobes oriented both toward Avellino (NE) and Naples (W-NW) (Mastrolorenzo et al., 1993). Significant damage resulted also from the load of tephra deposited in Napoli, as testified by the roof collapse occurred in a covered market of the Monteoliveto area (present municipality N. 4), which killed 11 people and injured 31. Table 1 summarizes these events deduced from the original documentary extracts by Lirer et al. (2009).

Collapsing columns from high magnitude Somma Vesuvio explosive events are expected to spread pyroclastic flows radially from the vent and possibly travel ca. $8 \mathrm{~km}$ far from the volcano (Esposti Ongaro, 2002; Lirer et al., 2010). Rolandi (2010) extends to $11 \mathrm{~km}$ the maximum travelled distance, by investigating the field occurrence of the pyroclastic flows of AD 79, AD 472 and AD 1631 eruptions. As a matter of fact, pyroclastic flow deposits of the Avellino eruption crop out in the Ponticelli-Barra area and were signalled by Rolandi et al. (1993b) even in the Napoli harbour area. Moreover, pyroclastic flow deposits of the Mercato-Ottaviano eruption were found in the buried successions of the Centro Direzionale area (Alberico et al., 2005), so testifying to the past emplacement of Somma Vesuvio explosive products at least in eastern part of the present Napoli city.

\subsection{Methodology}

The hazard map of Napoli municipality represents a subset of the multi-source volcanic hazard map of Campania Region (Lirer et al., 2010) integrated and partially modified with new data (Costa et al., 2009; Rolandi, 2010). Three different methodological approaches (Fig. 4) applied at Campi Flegrei volcanic field and Somma-Vesuvio central volcano were followed to assess the volcanic hazard for a future explosive event.
The first approach is a geo-spatial model implemented in a vector framework based on field data (Lirer et al., 2001), which allowed the contouring of the pyroclastic fall and flow hazard at Somma-Vesuvio; the second is a geo-spatial model implemented in a raster framework and based on simulation results aiming at assessing the pyroclastic flow hazard at Campi Flegrei (Alberico et al., 2002, 2008) while the third suitably processes the HAZMAP computational model results of Costa et al. (2009) to assess the pyroclastic fall hazard at Campi Flegrei.

In the appendix the methodology of the whole procedure is summarized, and the reader is invited to refer to our previously quoted papers for full details regarding the methodology of the first two steps.

The three-step procedure brought us to depict the maps of the Napoli areas exposed to pyroclastic fall and flows hazard from both volcanic sources. The areas with different degree of hazard delineated in the single maps were merged to obtain the Napoli city conditional volcanic hazard map (Fig. 5), where the single points record the possibility to be hit by the products of a new explosive event occurring at Campi Flegrei or Somma-Vesuvio.

Assuming that the past is a reasonable guide to the future behaviour of the volcano, the recurrence of past events has to be taken into account when assessing the volcanic hazard. Aiming at this for Campi Flegrei we processed the input data by means of the conditional probabilities of occurrence reported in Orsi et al. (2009). These authors, starting from the trial probability of occurrence that Simkin and Siebert (1994) deduced from the historically recorded explosive volcanic events, took into account the recurrence of variously sized explosive events at Campi Flegrei in the last $5 \mathrm{ka}$ and calculated conditional probabilities of occurrence for low, medium and high energy events of 0.6, 0.25, 0.037, respectively. These values depend on the number and the size of eruptive episodes recognized in the investigated time 


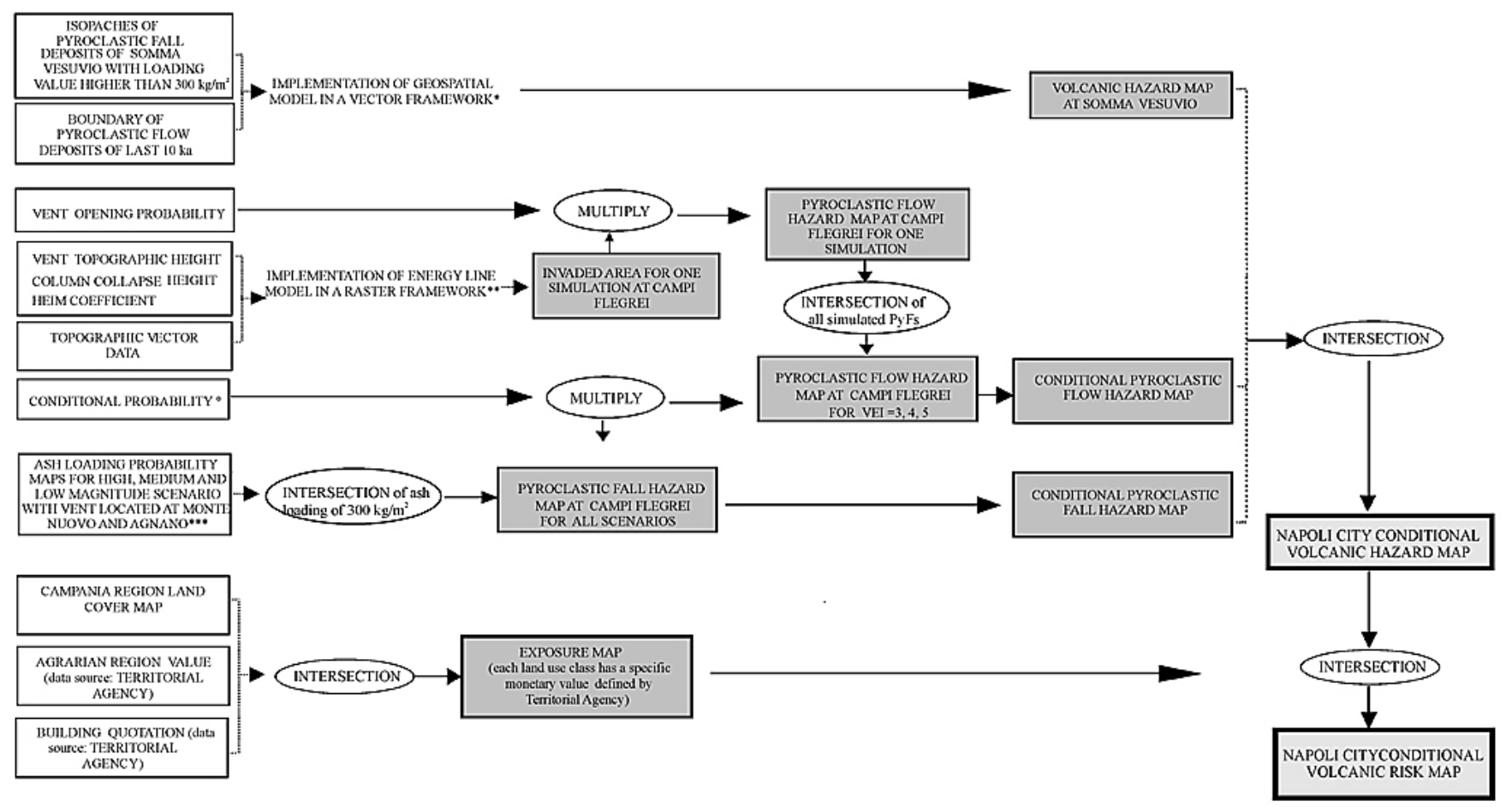

Fig. 4. Flow chart reporting the procedure for hazard and risk assessment. * Lirer et al. (2001), ** Alberico et al. (2002), *** Costa et al. (2009), ${ }^{\circ}$ Orsi et al. (2009), PyFs = pyroclastic flows

window. This is a crucial point at Campi Flegrei, where the almost total absence of historic activity and the difficulties in field survey caused by the intense urbanization, strongly bias the precise assessment of conditional probabilities of future occurrence. Once assumed the values of Orsi et al. (2009), they were here used to attribute a weight to the possible future occurrence of different sized explosive events.

\subsection{Hazard zoning}

Four different degrees of hazard were identified in the conditional volcanic hazard maps (Fig. 5):

1. H4 (high hazard for pyroclastic flow and fall) - this class corresponds to the eastern zone of municipality N. 6 (Ponticelli-Barra neighbourhood) and with Agnano plain, at Campi Flegrei. In the former, high damage to structures caused by the impact of pyroclastic flows from Somma Vesuvio is expected; in the latter both high damage by Campi Flegrei pyroclastic flows and the overload exerted on the roofs by pyroclastic fall deposits are expected. Within the Campi Flegrei caldera, the effect of low size eruptions is enhanced by high conditional probability of this kind of event.

2. H3 (medium hazard for pyroclastic flow and high hazard for pyroclastic fall) - this class is located in the lowland of Campi Flegrei, western sector of municipality
N. 10, and encircles the high hazard zones within the Campi Flegrei caldera. The spatial frequency of pyroclastic flows is lower than in $\mathrm{H} 4$ class, but damage to structures caused by both the impact of pyroclastic flows and the load exerted on the roofs by pyroclastic fall deposits is expected.

3. H2 (medium - low hazard for pyroclastic flow and medium hazard for pyroclastic fall) - this class encompasses the greatest part of municipalities N. 9 and N. 10 . This area displays a medium to low hazard for pyroclastic flow and medium hazard for pyroclastic fall products sourcing from Campi Flegrei.

4. The lowest hazard $\mathrm{H} 1$ class has been split into three subclasses, mostly exposed to Campi Flegrei activity:

- Low hazard for pyroclastic flow and medium hazard for pyroclastic fall - this class encircles the $\mathrm{H} 2$ area and encompasses municipalities N. 1, N. 5 and N. 8; in this area mostly damage by pyroclastic fall overload on roofs is expected.

- Very low hazard for pyroclastic flow and medium hazard for pyroclastic fall - this area is reached by pyroclastic flows of few simulations of VEI $=5$ eruptions and, taken into account the low values of conditional probability, the consequent hazard is very low. 


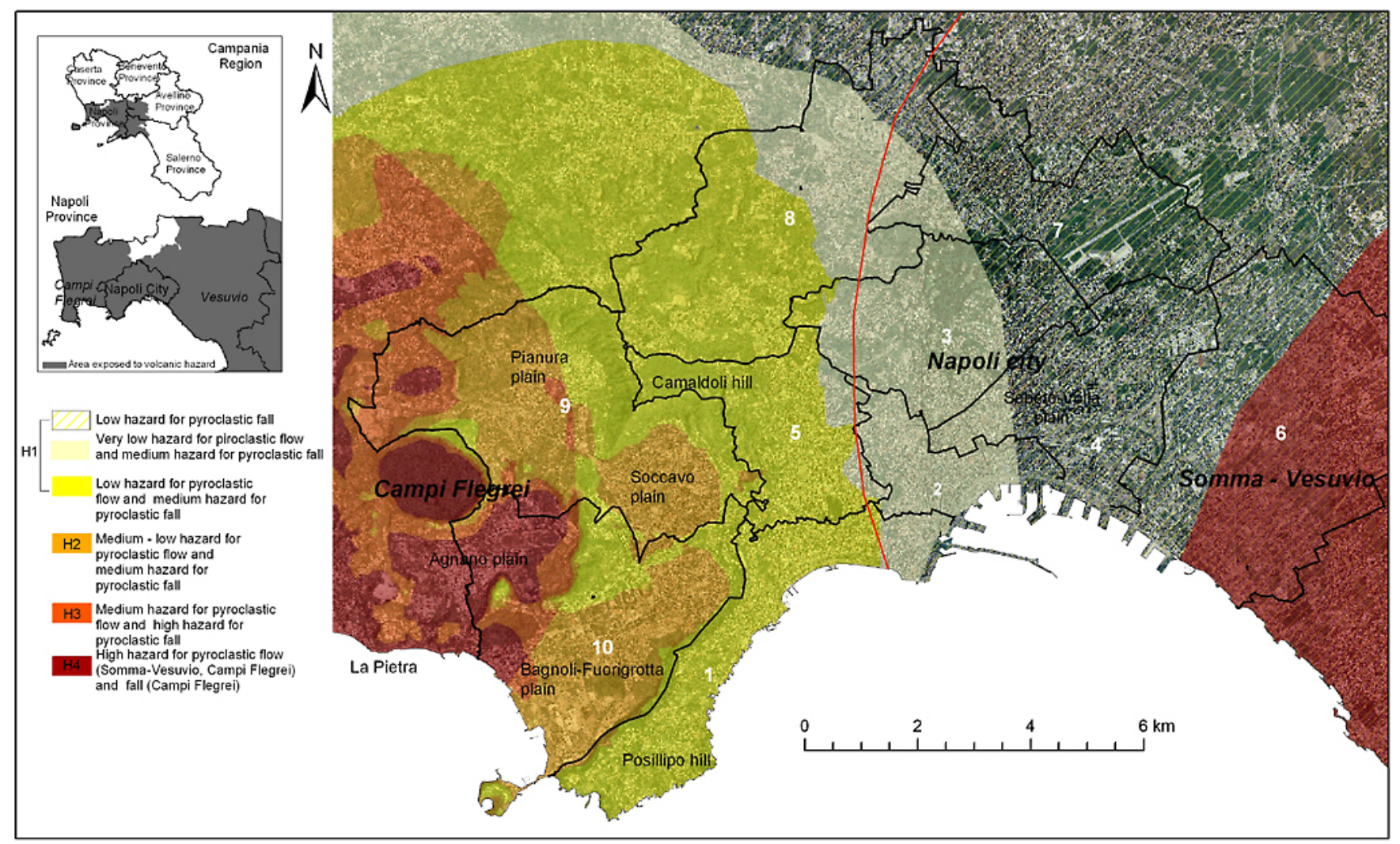

Fig. 5. Conditional volcanic hazard map of Napoli city. The red line represents the boundary of field mapped pyroclastic flow deposits of the Avellino eruption from Somma-Vesuvio (Rolandi et al., 1993b).

- Low hazard for pyroclastic fall - this area encompasses the municipalities N. 7 and N. 4, and could be only blanketed by pyroclastic fall deposits of the eruptions from the vent located in the Agnano area and in very few cases by plinian pumice fall deposits from Somma-Vesuvio volcano.

The map enhances, within the Campi Flegrei caldera, the role of the pyroclastic fall and flows of the low-size explosive events, considered the most probable in the next future (Costa et al., 2009; Orsi et al., 2009), owing to the higher conditional probability of future occurrence. In a similar way, it underestimates the possible effects of a pyroclastic fall emplacing event in the eastern Napoli area, because of the very low conditional probability value attributed to high size (Monte Spina-type) explosive events.

\section{The exposure map}

Starting from the idea that resident population of Napoli city can be got in safe before a new explosive eruption occurs in the future, the exposure is here represented as the economical value associated to the artefacts exposed to hazard. This economical value was defined through a simple two- step procedure, which makes it possible to assign the economical value defined by the Italian Territorial Agency in 2008-2009 (www.agenziaterritorio.it) to urban, agrarian and natural vegetation areas.

At this aim, three input data were used: the Land Use map of Campania Region at scale 1:50000, the Agrarian Region and the Urban Belts of Territorial Agency. The Land Use map reports the spatial distribution of agrarian cultivation and urban area of Napoli city; the Agrarian Region defines the economical value of agrarian cultivation and of natural vegetation with value changing in the five provinces of Campania Region; the urban belts correspond to zones of the single municipalities with different economical value.

In detail, the Land Use map was divided into two maps containing the agrarian and natural vegetation land use and the urban land use, respectively. The intersection of the first map with the Agrarian Region and of the second map with urban belts allowed to assign the economical value to each land use map of Campania Region (Fig. 6).

For agrarian and urban land uses two different classifications normalized according to the maximum value of the single parameter were retained. In the map clearly appears the highest value of urban area of municipality N. 1, characterized by residential buildings and villas and of the 
municipality N. 2 and N. 5 mainly corresponding to the historical centre of the city and to the Vomero-Arenella zone respectively. The economical value of urban area decreases moving from these municipalities toward the city boundary characterized by popular buildings and by an undersized transport system network.

Inside the Napoli city, the very few and narrow natural areas include vineyards, orchards, natural grasslands, pastures mainly located on the hills and mixed woods of Astroni wild park, of Capodimonte park and of northern slopes of Camaldoli hill. The highest economical value characterizes the few areas devoted to vegetable, and to complex cultivation patterns (brown-orange zones in Fig. 6), the intermediate values are typical of the few areas devoted to arable land and mixed wood (white and orange in Fig. 6), while the lowest economical value characterizes the natural grassland (yellow zones in Fig. 6).

\section{The volcanic risk map}

The risk formula $($ Risk $=$ Hazard $\times$ Exposure $\times$ Vulnerability $)$ of UNDRO (1979), posing the vulnerability $=1$, was used to draw the risk map (Fig. 7), which is the graphic result of the intersection of hazard and exposure maps. Attributing the maximum value of vulnerability (1) to all the exposure brings to an overestimation of risk, but the unavailability of a global vulnerability assessment over the entire study area, prevented the ranking of this parameter. As a consequence, our conditional risk map, depending on conditional hazard, is sensitive to the exposure and reflects the economical value of the artefacts possibly loose in case of renewal of explosive activity. Four risk classes, from high risk to very low risk, were identified and their spatial distribution reflects the results of hazard and exposure maps superimposition, so that the coincidence of low hazard with low exposure gives as result a low risk class and the opposite condition characterizes the areas with high hazard and high exposure (Fig. 7).

In Fig. 7 it is possible to observe the spatial distribution of risk classes; as an example, high risk characterizes the few polygons of vegetable gardens located at the foot slopes of Somma-Vesuvio, displaying both high hazard and exposure; the same features characterize the La Pietra coastal zone. Medium risk characterizes the eastern sector of Napoli city (part of municipality N. 6) and the Agnano Plain inside the Campi Flegrei caldera. In the former area the high hazard is associated to the lowest urban exposure value, whereas the high hazard and medium exposure values are typical of the Agnano plain. A low risk characterizes the Posillipo and Vomero hills where the low hazard is associated to high exposure. The very low risk typifies the central-eastern part of Napoli city, except the easternmost part of municipality N. 6, owing to the coincidence of low hazard with the low economical value of the urban area (Fig. 7).

\section{Conclusive remarks}

Napoli is the only mega-city in the world located within a multiple source volcanic area; it is sandwiched, in fact, between Somma-Vesuvio and Campi Flegrei, both currently experiencing a quiescence phase that will give way to future explosive activity (Lirer et al., 2010). We drew, at the municipality scale, new volcanic hazard and risk maps, which enlighten the most hazardous areas of Napoli city irrespective of the volcanic source and depict the relative risk. Several basic assumptions were made for this work:

- We assumed that a reactivation of Vesuvio and Campi Flegrei is equally likely.

- For Somma-Vesuvio, we used a field based approach (Lirer et al., 2001) ad did not take into account conditional probability of occurrence of any size future event. Although these values are available (Neri et al., 2008; Macedonio et al., 2008), they can be suitably used to process a great deal of data extracted from simulations, as our approach to Campi Flegrei testifies, but do not work likewise with the few input field data we stated to use starting from the hazard map of Lirer et al. (2010).

- For pyroclastic fall hazard assessment at Campi Flegrei the use of HAZMAP simulation at only two vents causes an underestimation of hazard for pyroclastic fall mainly within the Campi Flegrei caldera, as Selva et al. (2010) recently demonstrated; furthermore, the same zone undergoes the limits of using this model in proximal areas (Costa et al., 2009).

- For pyroclastic flow hazard assessment at Campi Flegrei, we used the simple 2-D energy cone scheme of Malin and Sheridan (1982). As a matter of fact, since column collapse, and associated PDC formation and propagation, involve extremely complex physical processes, the use 3-D of simulations models using different input parameters (e.g., source conditions, etc.) could better describe the effects of the topography on the pyroclastic flow run out.

- The unavailability of a global vulnerability assessment over the entire study area, prevented the ranking of this parameter and forced us to attribute the maximum value of vulnerability (1) to all the exposure. This assumption brought to an overestimation of risk over the whole study area.

The aforementioned assumptions and simplifications we introduced render the resulting maps an improvable and upgradable product, to move from conditional hazard/risk maps to real hazard/ risk maps. In our opinion, however, in their present state they can represent a vital tool for decisionmaking about territorial management and future planning. The conditional hazard map, for the first time, divides the 


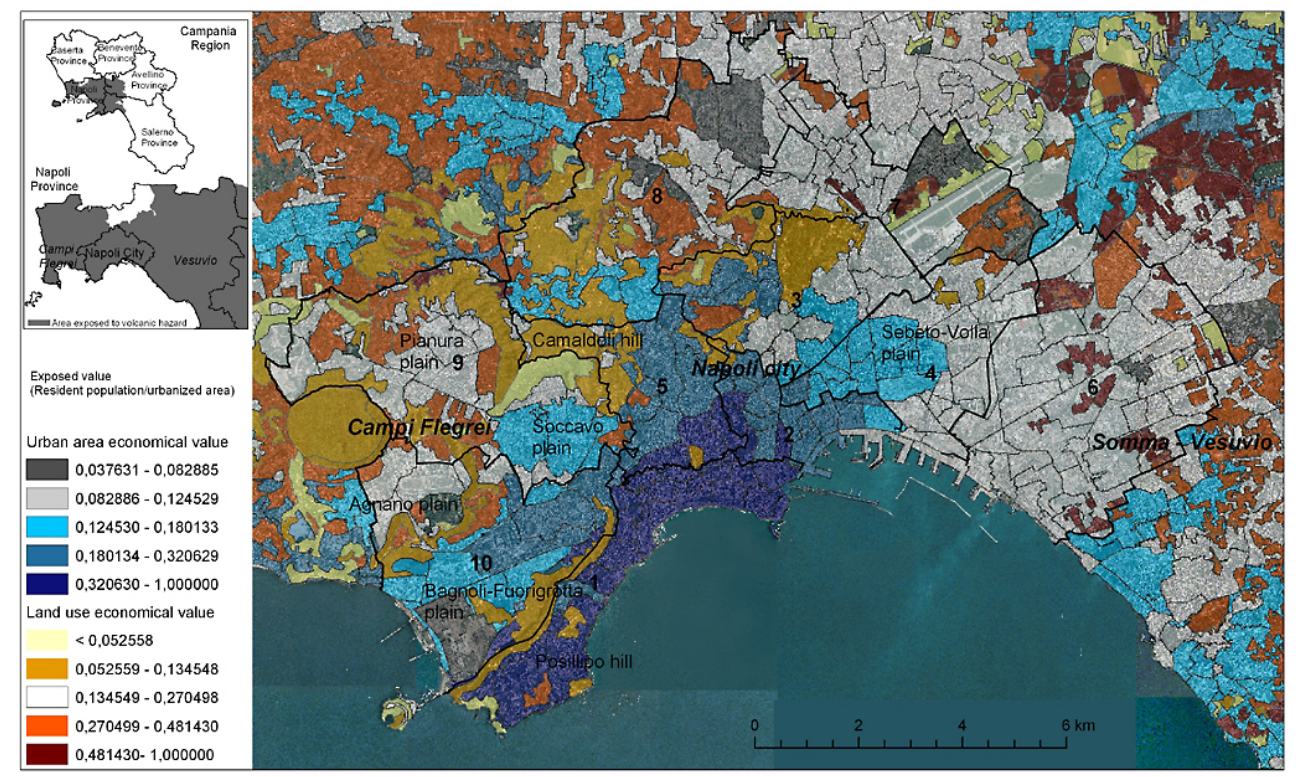

Fig. 6. Exposure map of single municipalities possibly involved by a future explosive event of the Somma-Vesuvio and Campi Flegrei active volcanic sources. The yellow-brown and the grey-blue scale colours indicate the exposure value for natural and urban land use, respectively.

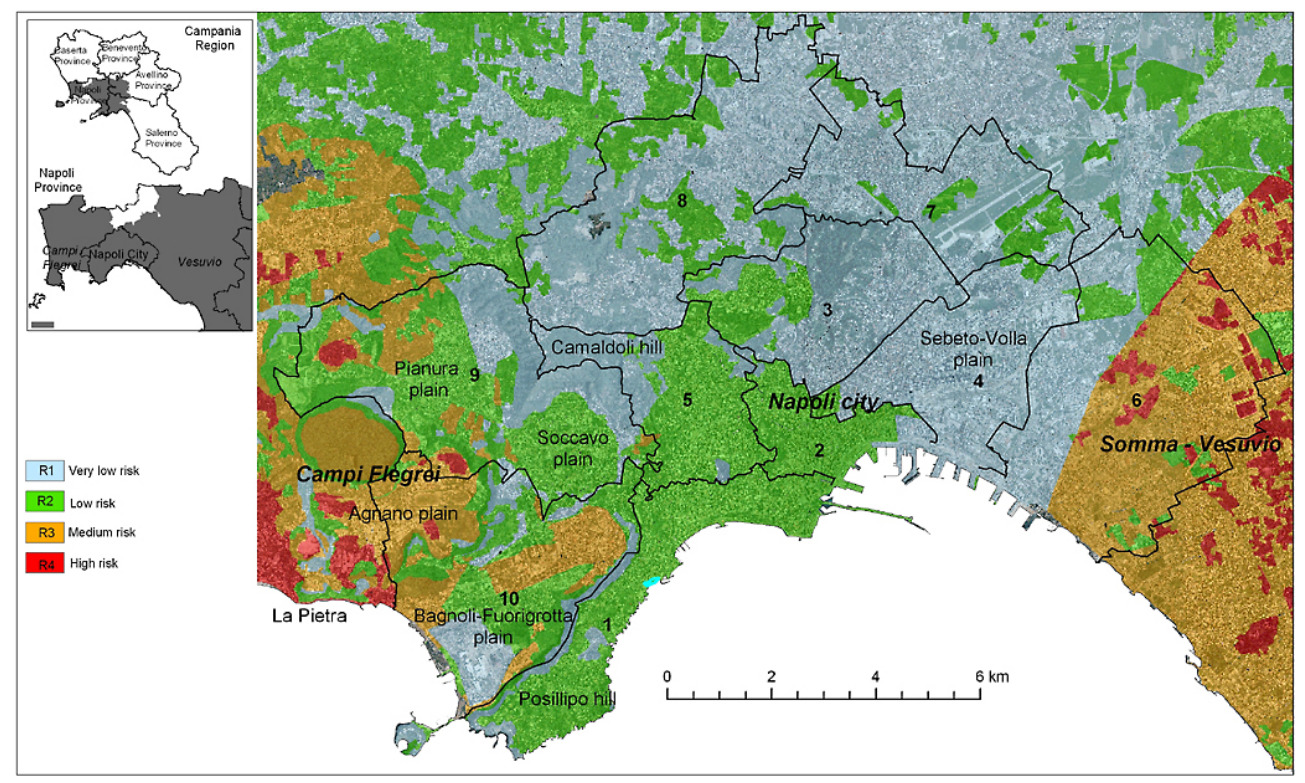

Fig. 7. Conditional volcanic risk map of Napoli city.

entire territory of Napoli city into four hazard classes. The high spatial probability to be hit by both the pyroclastic flows and fall originated by low to high magnitude eruptions is the main feature of the depressed areas of the western sector of the city, falling inside the Campi Flegrei caldera. Moving from these zones toward the hill slopes, the volcanic hazard decreases in response to the reducing spatial probability to be hit by pyroclastic flows.
The Napoli central area is mainly exposed to the fall products of Campi Flegrei eruptions, whose frequency progressively decreases toward the east causing a hazard variation from high to low. Nevertheless the results of recent studies must be taken into account since they confirmed the prevailing distribution towards the east for pyroclastic fall of Somma-Vesuvio plinian events, but at same time highlighted the possibility for future violent strombolian events to hit Napoli city. 
The eastern area of the city, corresponding with the ancient river Sebeto plain, is characterized by high hazard to be hit by the pyroclastic flows of Somma-Vesuvio and by fall products of both high-size Campi Flegrei and low-size Somma-Vesuvio eruptions.

Volcanic hazard map joined to exposure map gave us the possibility to draw the volcanic risk map for Napoli city, where the distribution of risk classes is clearly influenced by the spatial coincidence of classes with the same degree of both hazard and exposure. The medium risk characterizes both the eastern and western sector of Napoli while the low and very low risk classes prevail in the central area.

Our results yield to the conclusion that, contrary to the common people feeling and even local authorities perception, Napoli city is not volcanic risk-free, rather wide zones pertaining to it display a high probability to be endangered in case of a future event both from Campi Flegrei and SommaVesuvio. This consideration does not imply that terror must be stroke on the inhabitants, but that in territorial management and future planning the presence of the two volcanic sources cannot be disregarded.

The best proof of how much at present local Authorities neglect the possible exposition of artefacts to volcanic hazard can be found at Ponticelli-Barra, a sub-set of municipality N. 6, which results highly hazardous from our investigation, since in the last decades most of the new public housing of Napoli was built here and even the largest hospital in southern Italy (Ospedale del Mare - De Vivo et al., 2010; Rolandi, 2010) will be opened in a few months time in this high hazard zone. An other meaningful example is at Bagnoli were they are carrying out the remediation of the area occupied up to early Nineties by ILVA factory. The present development programme for Bagnoli plans to devote at least $30 \%$ of the ex-ILVA area to new houses, and last year this percentage was even raised with respect to the first plan. This is clearly contradictory with our results, because it would increase the number of people exposed to risk in an area of high-intermediate hazard. Many other examples could be found, testifying to the same carelessness of local authorities in this regard.

As a matter of fact, in the next future territorial planning in Napoli city is expected to take into much account the impending volcanic hazard and, in our opinion, the maps here depicted must be used to choose both the areas where new constructions can be built and those where it is necessary to reduce the demographic pressure aiming at lowering the number of people at risk.

\section{Appendix A}

In this following the methodology used to assess the volcanic hazard at Napoli city is summarized.

For Campi Flegrei, the first step was the assessment of vent opening probability. This factor describes the differ- ent spatial probabilities of future eruptive event sources for the different points of the volcanic field. It was quantified by parcelling the territory into square cells of $1 \mathrm{~km}$ side and applying the spatial analysis to the potential indicators (geovolcanological, geophysical and geo-chemical) of a renewal of volcanic activity (Scandone and D'Andrea, 1994). In a second phase, the "energy cone" model (Malin and Sheridan, 1982), which assumes column collapse heights of 100 , 300 and $500 \mathrm{~m}$ for eruptions of $\mathrm{VEI}=3$ and $\mathrm{VEI}=4$ and $\mathrm{VEI}=5$, with Heim coefficient equal to 0.1 , was used to perform 124 simulations. The simulations were centred in all the square cells previously used to quantify vent opening probability. The overlay of the energy cone to the Digital Elevation Model (Alberico et al., 2002) made it possible to automatically detect the invaded areas for each hypothesized vent for $\mathrm{VEI}=3,4$, and 5. Through the intersection of these areas, we drew a map for all VEIs depicting the spatial possibility of invasion by pyroclastic flows for each point of the territory. The areas delineated in the single maps were then multiplied by the conditional probability values of Orsi et al. (2009), to attribute a weight to the possible future occurrence of different sized explosive events. These areas were finally merged to depict the conditional hazard map for pyroclastic flows.

For pyroclastic fall hazard assessment, we used as input data the ash loading probability maps of low, medium, and high magnitude events with vents located in the AvernoMonte Nuovo and Agnano-San Vito areas, drawn by Costa et al. (2009), based on a threshold loading of $300 \mathrm{~kg} / \mathrm{m}^{2}$ (Dipartimento di Protezione Civile, 1995). The pyroclastic fall hazard was processed by using both the spatial frequency and the ash loading probability. We firstly merged the results of the simulations for each size at the two vents and obtained three maps depicting the hazard level as the spatial frequency of the range of ash loading probability (i.e. 5-10\%) reported by Costa et al. (2009). The areas delineated in the single maps were then multiplied by the conditional probability values of Orsi et al. (2009), to attribute a weight to the possible future occurrence of different sized explosive events. We finally merged these maps to draw a single map highlighting the different spatial frequencies of ash loading probability ranges for all the simulations and sizes, where single points record how many times the maximum sustainable loading was exceeded. Four hazard areas were finally defined: (a) both the very low and low hazard areas are characterized by $1-10 \%$ probability to be reached by fall products overwhelming the collapse threshold but the spatial probability to be reached by all the six eruptive scenarios considered is one and two respectively; (b) the medium hazard area is typified by the spatial probability to be reached by $3-4$ of all six eruptive scenarios considered and with collapse ash loading probability to be reached of $1-25 \%$; (c) the high hazard area is typified by the spatial probability to be reached by $5-6$ of all six eruptive scenarios considered and with collapse ash loading probability to be reached of $1-50 \%$. The areas contoured in the conditional hazard map for pyroclastic flows and for 
pyroclastic falls were finally merged to depict the conditional probability hazard map at Campi Flegrei.

For Somma-Vesuvio pyroclastic flows that could threaten the eastern area of Napol, we took into account the dynamic overpressure of ca. $5 \mathrm{kPa}$ calculated for the pyroclastic flow deposits of $79 \mathrm{AD}$ eruption, outcropping in the Terzigno area (Fraldi et al., 2002), about $8 \mathrm{~km}$ away from the vent. These values signify a high destructive power on both ancient Roman buildings and on present building typologies of the vesuvian area (Nunziante et al., 2003; Zuccaro et al., 2008). Because of this, we selected the areas overrun by the pyroclastic flows of the three main eruptions of the last $10 \mathrm{ka}$ (Avellino, $79 \mathrm{AD}, 472 \mathrm{AD}$ ) up to a $8 \mathrm{~km}$ distance from the vent. The intersection of these areas gives a "frequency map", where single points record how many times the destructive threshold was overwhelmed in the past $10 \mathrm{ka}$.

Pyroclastic fall hazard assessment at Somma-Vesuvio was based on the isopach maps reported in Lirer et al. (2001) for the explosive events of the last $10 \mathrm{ka}$. The loadings of different thickness of pyroclastic fall deposits have been taken into account to define, for each eruption, the area encompassed by the maximum load sustainable by roofs, as stated by the Civil Defence Department at $300 \mathrm{~kg} / \mathrm{m}^{2}$ (Dipartimento di Protezione Civile, 1995). The intersection of these areas gives a "frequency map", where single points record how many times the maximum sustainable loading was exceeded in the past $10 \mathrm{ka}$.

The ranking of frequency values, according to the natural break method, allowed us to define seven hazard classes for both pyroclastic flows and pyroclastic fall from the single source which emplaced pyroclastic deposits in Napoli. The natural break method identifies groups and patterns of data in a set by defining the separation points among the frequency values and minimizing the variance in each class (Jenks and Caspall, 1971).

Acknowledgements. The authors wish to gratefully thank B. De Vivo and two anonymous reviewers for thoughtful and constructive comments on the manuscript. A sincere thank-you goes to the chief editor G. Macedonio whose suggestions greatly improved the paper.

Edited by: G. Macedonio

Reviewed by: B. De Vivo and two other anonymous referees

\section{References}

AGIP: Geologia e geofisica del sistema geotermico dei Campi Flegrei, Int. Report, 1-17, 1987.

Alessio, M., Bella, F., Improta, S., Belluomini, G., Cortesi, C., and Turi, F.: University of Rome Carbon-14 dates X, Radiocarbon, 15, 165-178, 1973.

Alberico, I., Lirer, L., Petrosino, P., and Scandone, R.: A methodology for the evaluation of volcanic risk in Campi Flegrei, J. Volcanol. Geother. Res., 116, 63-78, 2002.
Alberico, I., Petrosino, P. Zeni, G. D'Andrea, F., and Lirer, L.: GEOCITY: a drill-hole database as tool to assess geological hazard in Napoli urban area, Environ. Geol., 47, 751-762, 2005.

Alberico, I., Lirer, L., Petrosino, P., and Scandone, R.: Volcanic hazard and risk assessment from pyroclastic flows at Ischia island (Southern Italy), J. Volcanol. Geotherm. Res., 171, 118136, 2008.

Andronico, D. and Cioni, R.: Contrasting styles of Mount Vesuvius activity in the period between the Avellino and Pompeii Plinian eruptions, and some implications for assessment of future hazards, Bull. Volcanol., 64, 372-391, 2002.

Araña, V., Felpeto, A., Astizba, M., García, A., Ortiza, R., and Abella, R.: Zonation of the main volcanic hazards (lava flows and ash fall) in Tenerife, Canary Islands. A proposal for a surveillance network, J. Volcanol. Geother. Res., 103(1-4), 377-391, 2000.

Arrighi, S., Principe, C., and Rosi, M. Violent strombolian and subplinian eruptions at Vesuvius during post-1631 activity, Bull. Volcanol., 63, 126-150, 2001.

Barberi, F., Macedonio, G., Pareschi, M. T., and Santacroce, R.: Mapping the tephra fallout risk: an example from Vesuvius, Italy, Nature, 344, 142-144, 1990.

Bellucci, F.: Nuove conoscenze stratigrafiche sui depositi vulcanici del sottosuolo del settore meridionale della Piana Campana, Boll. Soc. Geol. It., 113, 395-420, 1994.

Bellucci, F., Milia, A., Rolandi, G., and Torrente, M. M.: Structural control on the Upper Pleistocene ignimbrite eruptions in the Neapolitan area (Italy): volcano tectonic faults versus caldera faults, in: Volcanism in the Campania Plain: Vesuvius, Campi Flegrei, Ignimbrites, edited by: De Vivo, B., Elsevier, Developments in Volcanology, 9, 163-180, 2006.

Behncke, B., Neri, M., Pecora, E., and Zanon, V.: The exceptional activity and growth of the Southeast Crater, Mount Etna (Italy), between 1996 and 2001, Bull. Volcanol., 69, 149-173, 2006.

Carrara, E., Iacobucci, F., Pinna, E., and Rapolla, A.: Gravity and magnetic survey of the Campanian Volcanic Area, Southern Italy, Boll. Geof. Teor. e Appl., 15, 39-51, 1973.

Carrara, E., Iacobucci, F., Pinna, E., and Rapolla, A.: Interpretation of gravity and magnetic anomalies near Naples, Italy using computer techniques, Bull. Volcanol., 38(2), 458-467, 1974.

Cinque, A., Rolandi, G., and Zamparelli, V.: L'estensione dei depositi marini olocenici nei Campi Flegrei in relazione alla vulcano-tettonica, Boll. Soc. Geol. It., 104, 327-348, 1985.

Cinque, A., Aucelli, P. P. C., Brancaccio, L., Mele, R., Milia, A., Robustelli, G., Romano, P., Russo, F., Russo, M., Santangelo, N., and Sgambati D.: Volcanism, tectonics and recent geomorphological change in the bay of Napoli, Suppl. Geogr. Fis. Dinam. Quat, III, T.2, 123-141, 1997.

Cioni, R., Santacroce, R., and Sbrana, A.: Pyroclastic deposits as a guide for reconstructing the multi-stage evolution of the SommaVesuvius caldera, Bull. Volcanol., 60, 207-222, 1999.

Cioni, R., Longo, A., Macedonio, G., Santacroce, R., Sbrana, A., Sulpizio, R., and Andronico, A.: Assessing pyroclastic fall hazard assessment through field data \& numerical simulation: Example from Vesuvio, J. Geophys. Res., 103(B2), 2063, doi:10.1029/2001JB000642, 2003.

Costa, A., Dell'Erba, F., Di Vito, M. A., Isaia, R., Macedonio, G., Orsi, G., and Pfeiffer, T.: Tephra fallout hazard assessment at the Campi Flegrei caldera (Italy), Bull. Volcanol., 71, 259-273, 
2009.

Daniele, P., Lirer, L., Petrosino, P., Spinelli, N., and Peterson, R.: Applications of the PUFF model to forecasts of volcanic clouds dispersal from Etna and Vesuvio, Comput. Geosci., 35, 10351049, 2009.

D'Argenio, B., Pescatore, T. S., and Scandone, P.: Schema geologico dell'Appennino Meridionale, Accad. Naz. Lincei Quad., 183, 49-72, 1973.

Deino, A. L., Orsi, G., de Vita, S., and Piochi, M.: The age of the Neapolitan Yellow Tuff caldera-forming eruption (Campi Flegrei caldera-Italy) assessed by 40Ar/39Ar dating method, J. Volcanol. Geother. Res., 133, 157-170, 2004.

de Vita, S., Orsi, G., Civetta, L., Carandente, A., D’Antonio, M., Deino, A., di Cesare, T., Di Vito, M. A., Fisher, R. V., Isaia, R., Marotta, E., Necco, A., Ort, M., Pappalardo, L., Piochi, M., and Southon, J.: The Agnano-Monte Spina eruption (4100 years BP) in the restless Campi Flegrei caldera (Italy), J. Volcanol. Geotherm. Res., 91, 269-301, 1999.

De Vivo, B., Rolandi, G., Gans, P.B., Calvert, A., Bohrson, W.A., Spera, F.J., and Belkin, H.E.: New constraints on the pyroclastic eruptive history of the Campanian volcanic Plain (Italy), in: Mt. Somma Vesuvius and Volcanism of the Campania Plain, edited by: De Vivo, B. and Rolandi, G., Spec. Issue Mineral. Petrol., 73, 47-65, 2001.

De Vivo, B., Petrosino, P., Lima, A., Rolandi, G., and Belkin H. E.: Research progress in volcanology in Neapolitan area, southern Italy: a review and alternative views, Mineral. Petrol., 99, 1-28, 2010.

Di Girolamo, P., Ghiara, M. R., Lirer, L., Munno, R., Rolandi, G., and Stanzione, D.: Vulcanologia e Petrologia dei Campi Flegrei, Boll. Soc. Geol. It., 103-2, 349-413, 1984.

Di Lillo, R.: Correlazioni tefrostratigrafiche tra gravity cores del Golfo di Gaeta e di Pozzuoli, Dip. Scienze della Terra University Federico II, Unpubl. Thesis, Napoli, 1, 122, 2001.

Dipartimento della Protezione Civile: Pianificazione nazionale di emergenza dell'area vesuviana. Presidenza del Consiglio dei Ministri Roma 1995, 1-55, 1995.

Di Vito, M. A., Isaia, R., Orsi, G., Southon, J., de Vita, S., D'Antonio, M., Pappalardo, L., and Piochi, M.: Volcanism and deformation since 12,000 years at the Campi Flegrei caldera (Italy), J. Volcanol. Geotherm. Res., 91(2-4), 221-246, 1999.

Esposti Ongaro, T., Neri, A., Todesco, M., and Macedonio, G.: Pyroclastic flow hazard assessment at Vesuvio (Italy) by using numerical modelling II Analysis of flow variables, Bull. Volcanol., 64, 178-191, 2002

Felpeto, A., Marti, J., and Ortiz, R.: Authomatic GIS-based system for volcanic hazard assessment, J. Volcanol. Geotherm. Res., 166, 106-116, 2007.

Finetti, I. and Morelli, C.: Esplorazione sismica a riflessione dei golfi di Napoli e Pozzuoli, Boll. Geof. Teor. E Appl., 16, 175222, 1974

Fraldi, M., Lirer, L., Nunziante, L., Petrosino, P., Scotellaro, S., and Cicirelli ,C.: Analysis of AD 79 eruption pyroclastic currents impact and present risk assessment for buildings at Vesuvio. AGU Chapman Conference on Volcanism and the Earth's atmosphere, Santorini, Greece, 17-21 June 2002, 2002.

Gómez-Fernández, F.: Application of a GIS algorithm to delimit the areas protected against basic lava flow invasion on Tenerife Island, J. Volcanol. Geoth. Res., 103(1-4), 409-423, 2000.
Insinga, D., Molisso, F., Lubritto, C., Sacchi, M., Passariello, I., and Morra, V.: The proximal marine record of Somma-Vesuvius volcanic activity in the Naples and Salerno bays, Eastern Tyrrhenian Sea, during the last 3 kyrs, J. Volcanol. Geotherm. Res., 177, 170-196, 2008.

Ippolito, F., Ortolani, F., and Russo, M.: Struttura marginale tirrenica dell'Appennino Campano: reinterpretazione di dati di antiche ricerche di idrocarburi, Mem. Soc. Geol. Ital., XII, 227250, 1973.

Isaia R., D'Antonio, M., Dell'Erba, F., Di Vito, M., and Orsi, G.: The Astroni volcano: the only example of closely spaced eruptions in the same vent area during the recent history of the Campi Flegrei caldera (Italy), J. Volcanol. Geotherm. Res., 133, 171192, 2004.

Italian Territorial Agency: www.agenziaterritorio.it, last access: May to November 2009

Jenks, G. F. and Caspall, F. C.: Error on choroplethic maps: definition, measurement, reduction, Ann. Assoc. Am. Geog., 61, 217 244, 1971.

Lirer, L.: Antonio Scherillo: il padre della cartografia geologica in aree urbane, in: Atti del Convegno "100 anni per la scienza in onore di Antonio Scherillo), edited by: Ghiara, M. R., Mottana, A., and Sbordone, C., 79-83, 2008.

Lirer, L., Petrosino, P., and Alberico, I.: Volcanic hazard assessment at volcanic fields: the Campi Flegrei case history, J. Volcanol. Geother. Res., 101(1-4), 55-75, 2001.

Lirer, L., Petrosino, P., Munno, R., and Grimaldi, M.: Vesuvius through history and science, Electa Mondatori, Napoli, 1-160, 2009.

Lirer, L., Petrosino, P., and Alberico, I.: Hazard and risk assessment in a complex multi-source volcanic area: the Campanian case history, Bull. Volcanol., 72, 411-429, 2010.

Macedonio, G., Costa, A., and Folch, A.: Ash fallout scenarios at Vesuvius: numerical simulations and implications for hazard assessment, J. Volcanol. Geotherm. Res., 178, 366-377, 2008.

Malin, M. C. and Sheridan, M. F.: Computer-assisted mapping of pyroclastic surges, Science, 217, 637-640, 1982.

Mastrolorenzo, G., Munno, R., and Rolandi, G.: Vesuvius 1906: a case study of a paroxysmal eruption and its relation to eruption cycles, J. Volcanol. Geotherm. Res., 58, 217-237, 1993.

Mastrolorenzo, G., Pappalardo, L., Troise, C., Rossano, S., Panizza, A., and de Natale, G.: Volcanic hazard assessment at the Campi Flegrei caldera, Geological Society of London, Special Pub., 269, 159-171, 2006.

Neri, A., Aspinall, W. P., Cioni, R., Bertagnini, A., Baxter, P. J., Zuccaro, G., Andronico, D., Barsotti, S., Cole, P. D., Esposti Ongaro, T., Hincks, T. K., Macedonio, G., Papale, P., Rosi, M., Santacroce, R., and Woo, G.: Developing an Event Tree for Probabilistic Hazard and Risk Assessment at Vesuvius, J. Volcanol. Geotherm. Res., 178(3), 397-415, 2008.

Nunziante, L., Fraldi, M., Lirer, L., Petrosino, P., Scotellaro, S., and Cicirelli, C.: Analysis of AD 79 eruption pyroclastic currents impact and present risk assessment for buildings at Vesuvio, Bull. Volcanol., 65, 154-176, 2003.

Orsi, G., de Vita, S., and Di Vito, M. A.: The restless, resurgent Campi Flegrei nested caldera (Italy): Constraints on its evolution and configuration, J. Volcanol. Geotherm. Res., 74, 179214, 1996

Orsi, G., Di Vito, M. A., and Isaia, R.: Volcanic hazard assessment 
at the restless Campi Flegrei caldera, Bull. Volcanol., 66, 514530, 2004.

Orsi, G., di Vito, M. A., Selva, J., and Marzocchi, W.: Longterm forecast of eruption style and size at Campi Flegrei caldera (Italy), Earth Planet. Sci. Lett., 287, 265-276, 2009.

Pareschi, M. T., Cavarra, L., Favalli, F., Gianni, F., and Meriggi, A.: GIS and volcanic risk management, Natural Hazards, 21, 361379, 2000.

Petrosino, P., Alberico, I., Caiazzo, S., Dal Piaz, A., Lirer, L., and Scandone, R.: Volcanic risk and evolution of the territorial system in the volcanic areas of Campania, Acta Vulcanol., 16 (1-2), 163-178, 2004.

Perrotta, A., Scarpati, C., Luongo, G., and Morra, V.: The Campi Flegrei caldera boundary in the city of Naples, in: Volcanism in the Campania Plain: Vesuvius, Campi Flegrei, Ignimbrites, edited by: De Vivo, B., Elsevier, Developments in Volcanology, 9, 85-96, 2006.

Rittmann, A., Vighi, L., Falini, F., Ventriglia, V., and Nicotera, P.: Rilievo geologico dei Campi Flegrei, Boll. Soc. Geol. It., 69, 117-362, 1950.

Rolandi, G.: Volcanic hazard at Vesuvius: Revising the current emergency plan, J. Volcanol. Geotherm. Res., 189, 347-362, 2010.

Rolandi, G., Maraffi, S., Petrosino, P., and Lirer, L.: The Ottaviano Eruption of Somma-Vesuvio (8000 Y. B.P.): a magmatic alternating fall and flow forming eruption, J. Volcanol. Geotherm. Res., 58, 43-65, 1993a.

Rolandi, G., Mastrolorenzo, G., Barrella, A. M., and Borrelli, A.: The Avellino Plinian eruption of Somma-Vesuvius (3760 y $\mathrm{BP})$ : The progressive evolution from magmatic to hydromagnatic style, J. Volcanol. Geotherm. Res., 58, 67-88, 1993 b.

Rolandi, G., Petrosino, P., and McGeehin, J.: The interplinian activity of Somma-Vesuvius in the last 3500 years, J. Volcanol. Geotherm. Res., 81, 19-52, 1998.

Rolandi, G., Paone, A., Di Lascio, M., and Stefani, G.: The 79 AD eruption of Somma: The relationship between the date of the eruption and the southeast tephra dispersion, J. Volcanol. Geotherm. Res., 169, 87-98, 2007.
Rosi, M. and Sbrana, A.: The Phlegrean Fields, C. N. R. Quad. Ric. Sci., 114, 1-175, 1987.

Santacroce, R.: Somma-Vesuvius, Consiglio Nazionale delle Ricerche Quaderni Ricerca Scientifica, 114(9), 1-251, 1987.

Scandone R. and D'Andrea, M.: Il rischio vulcanico, in: Di Donna, V. and Vallario, A., "L'ambiente: Risorse e rischi" Liguori, Napoli, 130-150, 1994.

Scherillo, A.: I tufi antichi di S. Maria Apparente e Via Parco Grifeo in Napoli, Boll. Soc. Natur. Napoli, 16, 27-37, 1957.

Selva, J., Costa, A., Marzocchi, W., and Sandri, L.: BET_VH: exploring the influence of natural uncertainties on long-term hazard from tephra fallout at Campi Flegrei (Italy), Bull. Volcanol., 72(6), 717-733, 2010.

Simkin, T. and Siebert, L.: Volcanoes of the world: a regional directory, gazetteer, and chronology of volcanism during the last 10000 years (second edition), Smithsonian Institution and Geoscience Press Inc., Tucson, 1994.

Todesco, M., Neri, A., Esposti Onagro, T., Papale, P., and Rosi, M.: Pyroclastic flow dynamics and hazard in a caldera setting: Application to Phlegrean Fields (Italy), Geochem. Geophy. Geosy., 7(11) Q11003, doi:10.1029/2006GC001314, 2006.

Toyos, G. P., Cole, P. D., Felpeto, A., and Martí, J.: A GIS-based methodology for hazard mapping of small pyroclastic density currents, Natural Hazards, 41(1), 99-112, 2007.

Widiwijayanti, C., Voight, B., Hidayat, D., and Schilling S. P.: Objective rapid delineation of areas at risk from block-and-ash pyroclastic flows and surges, Bull. Volcanol., 71, 687-703, 2009.

UNDRO: Natural Disasters and Vulnerability Analysis, in Report of Expert Group Meeting (9-12 July 1979), UNDRO (United Nations Disaster Relief Coordinator), Geneva, 1979.

Zuccaro, G., Cacace, F., Baxter, P. J., and Spence, R.: Impact of explosive scenarios at Vesuvius, J. Volcanol. Geotherm. Res., 178, 416-453, 2008. 